\title{
Uji Daya Hasil Lanjutan Tomat (Solanum lycopersicum L.) Populasi F8
}

\section{Advanced Yield Trials of F8 Population Tomatoes (Solanum lycopersicum L.)}

\section{Lisa Sentani, Muhamad Syukur ${ }^{*}$, Siti Marwiyah}

\author{
Departemen Agronomi dan Hortikultura, Fakultas Pertanian, Institut Pertanian Bogor (Bogor \\ Agricultural University), Jalan Meranti, Kampus IPB Darmaga, Bogor 16680, Indonesia \\ Telp.\& Faks.0251-8629353 e-mail agronipb@indo.net.id \\ *Penulis untuk korespondensi: muhsyukur@yahoo.com
}

Disetujui 18 Januari 2016 / Published online 25 Januari 2016

\begin{abstract}
The main problem of the cultivation of tomato plants in the lowlands is the limited high yield varieties. The aim of this research was to test yield of $F 8$ population tomatoes. The research was conducted at IPB Experimental Field, Leuwikopo, Dramaga, Bogor, from February until June 2015. The experimental design used Randomized Completely Block Design, single factor and three replications. The factor was 13 genotypes and two commercial varieties (Intan and Ratna) as comparison. The result showed that all genotypes had determinate growth type. All of genotypes had the same leaf shape and inflorescence type with the compared varieties Intan and Ratna. The genotypes significantly affect the overall character. The tomato genotypes that had the better yield than the other genotypes and the compared varieties Intan are F8 005001-4-1-12-3-87-3 and F8 005001-4-1-12-3-66-1 (number and weight fruit per plant is higher). The highest productivity and weight per fruit was the genotype F8 005001-4-1-12-3-87-3. All of genotypes had better fruit length, flesh thickness, and total dissolved solids than Intan variety.
\end{abstract}

Keywords: genotype, productivity, tomato, yield

\begin{abstract}
ABSTRAK
Permasalahan utama pada budi daya tanaman tomat di dataran rendah adalah kurang tersedianya varietas unggul yang berdaya hasil tinggi. Penelitian ini bertujuan untuk menguji daya hasil genotipe tomat populasi F8. Penelitian dilakukan di Kebun Percobaan Leuwikopo IPB, Dramaga, Bogor pada bulan Februari hingga Juni 2015. Percobaan menggunakan Rancangan Kelompok Lengkap Teracak (RKLT), satu faktor dengan tiga ulangan. Faktor tersebut adalah genotipe yang terdiri atas 13 genotipe tomat dan dua varietas komersial (Intan dan Ratna) sebagai pembanding. Hasil penelitian menunjukkan bahwa seluruh genotipe memiliki tipe pertumbuhan determinate. Seluruh genotipe memiliki bentuk daun dan bentuk tandan buah yang sama dengan varietas pembanding Intan dan Ratna. Seluruh genotipe berpengaruh nyata terhadap keseluruhan karakter. Genotipe tomat yang memiliki daya hasil lebih baik dari genotipe lainnya dan varietas pembanding Intan adalah F8 005001-4-1-12-3-87-3 dan F8 005001-4-1-12-3-66-1 (jumlah dan bobot buah per tanaman lebih tinggi). Produktivitas dan bobot per buah yang paling tinggi dimiliki oleh genotipe F8 005001-4-1-12-3-87-3. Seluruh genotipe memiliki panjang buah, tebal daging buah, dan padatan terlarut total yang lebih baik dari varietas pembanding Intan.
\end{abstract}

Kata kunci: daya hasil, genotipe, produktivitas, tomat 


\section{PENDAHULUAN}

Tomat (Solanum lycopersicum L.) merupakan tanaman hortikultura yang sangat penting dalam menunjang ketersediaan pangan dan kecukupan gizi masyarakat, namun masih memerlukan penanganan yang serius. Produktivitas rata-rata tomat $\mathrm{di}$ Indonesia menurun dari 16.61 ton ha $^{-1}$ pada tahun 2013 menjadi 15.52 ton ha ${ }^{-1}$ pada tahun 2014 . Penurunan tersebut disebabkan karena produksi tomat yang menurun (Ditjenhorti, 2015).

Menurut Purwati (2007) produktivitas tomat di dataran rendah sebesar 6.0 ton $\mathrm{ha}^{-1}$, angka ini sangat rendah dibandingkan dengan produktivitas di dataran tinggi yakni sebesar 26.60 ton $\mathrm{ha}^{-1}$. Varietas tomat yang pada awalnya hanya cocok ditanam di dataran tinggi, saat ini sudah banyak varietas tomat untuk dataran medium dan dataran rendah, namun pengembangan tomat di dataran rendah masih memiliki beberapa kendala berupa penurunan daya hasil. Hal ini dapat disebabkan antara lain kultur teknis yang kurang optimal, serangan hama dan penyakit, dan masih sedikitnya varietas yang berdaya hasil tinggi. Menurut Surmaini dan Runtunuwu (2008), salah satu faktor yang mempengaruhi rendahnya produksi di dataran rendah adalah suhu. Perbedaan suhu dapat mengakibatkan perbedaan respon tanaman, dimana peningkatan suhu menyebabkan peningkatan transpirasi tanaman sehingga terjadi penurunan produktivitas tanaman, peningkatan konsumsi air, waktu pematangan buah atau biji yang singkat, penurunan mutu hasil, dan pendorong berkembangnya hama penyakit tanaman.

Peningkatan produksi tomat dapat dilakukan salah satunya melalui program pemuliaan tanaman, yaitu dengan merakit varietas unggul baru tomat. Perakitan varietas baru diarahkan untuk meningkatkan potensi hasil dan mutu sehingga varietas baru mempunyai daya kompetitif tinggi (Ambarwati et al., 2009). Varietas-varietas tersebut diharapkan dapat dibudi dayakan dengan produksi tinggi dan kualitas yang baik. Kemampuan tanaman tomat untuk dapat menghasilkan buah sangat tergantung pada interaksi antara pertumbuhan tanaman dan kondisi lingkungannya (Wijayani dan Widodo, 2005). Masalah yang sering dihadapi dalam penggunaan galur-galur potensial tomat adalah adanya perbedaan hasil tomat bila ditanam pada lingkungan yang berbeda, untuk itu diperlukan pengujian daya hasil tomat pada kondisi lingkungan yang sesuai dengan kondisi tempat suatu varietas akan dibudi dayakan.

Tahapan uji daya hasil adalah uji daya hasil pendahuluan, uji daya hasil lanjutan, dan uji multilokasi (uji adaptasi). Uji daya hasil merupakan aspek penting dalam program perakitan varietas baru. Pemilihan atau seleksi dalam pengujian terhadap galur-galur unggul homozigot masih dilakukan yang bertujuan untuk memilih salah satu atau beberapa galur terbaik (Kuswanto et al., 2005). Kuswanto et al. (2009) mengatakan uji daya hasil pendahuluan adalah uji daya hasil di mana jumlah galur yang diuji relatif sangat banyak tetapi jumlah benihnya masih sangat sedikit. Galur-galur yang memiliki harapan untuk dilepas sebagai varietas unggul pada uji daya hasil pendahuluan akan digunakan untuk uji daya hasil lanjutan.

\section{BAHAN DAN METODE}

Penelitian dilaksanakan di Kebun Percobaan Leuwikopo, IPB, Dramaga, Bogor dan Laboratorium Pascapanen Departemen Agronomi dan Hortikultura, IPB. Penelitian dilaksanakan pada bulan Februari sampai Juni 2015. Bahan tanaman yang diuji terdiri dari 13 genotipe potensial tomat, yaitu F8 005001-4-1-12-3-17-1, F8 005001-4-1-12-3-17-2, F8 005001-4-1-12-348-3, F8 005001-4-1-12-3-17-4, F8 005001-4-112-3-87-3, F8 005001-4-1-12-3-8-1, F8 0050014-1-12-3-54-1, F8 005001-4-1-12-3-66-1, F8 005001-4-1-12-3-46-2, F8 005001-4-1-12-3-66-2, F8 005001-4-1-12-3-88-1, F8 005001-4-1-12-338-2, dan F8 005001-4-1-12-3-48-1 dengan 2 varietas pembanding, yaitu Intan dan Ratna. Pupuk yang digunakan adalah pupuk kandang, NPK dengan konsentrasi $10 \mathrm{~g} \mathrm{~L}^{-1}$, serta kapur. Pestisida yang digunakan yaitu insektisida dengan bahan aktif karbosulfan $5 \%$, beta siflutrin $28 \mathrm{~g} \mathrm{~L}^{-1}$, prefenofos $500 \mathrm{~g} \mathrm{~L}^{-1}$, carbofuran $3 \%$, dan fungisida sistemik berbahan aktif propineb $70 \%$ dengan konsentrasi $2 \mathrm{~g} \mathrm{~L}^{-1}$. Alat yang digunakan dalam penelitian meliputi ajir, meteran, tray, label, mulsa plastik hitam perak, penggaris, plastik, timbangan digital, alat tulis, kamera digital, penetrometer, hand refractrometer, jangka sorong digital, dan alat-alat pertanian umum.

Pelaksanaan penelitian dimulai dengan penyemaian benih. Benih tomat disemai dalam tray berisi media tanam dan pupuk kandang dengan perbandingan 2:1. Penyiraman persemaian dilakukan setiap pagi dan sore. Persiapan lahan dan pengolahan tanah meliputi pembersihan lahan dari gulma dan penggemburan tanah, kemudian dibiarkan selama satu minggu. Mulsa plastik hitam perak (MPHP) dipasang pada bedengan dan dibuat lubang tanam dengan jarak $50 \mathrm{~cm} \times 50 \mathrm{~cm}$. Penanaman dilakukan dengan cara transplanting setelah bibit tomat berumur empat minggu. Penanaman dilakukan pada sore hari dengan memasukkan bibit tomat ke dalam lubang tanam. Pemasangan ajir dilakukan bersamaan dengan waktu pindah tanam bibit. Penyulaman dilakukan sejak 1 hingga 14 hari setelah tanam (HST). 
masa penanaman meliputi penyiraman, penyiangan gulma, pengajiran, pewiwilan, pemupukan, serta pengendalian hama dan penyakit tanaman (HPT). Penyiraman dilakukan setiap pagi dan sore hari sampai keadaan tanah menjadi lembab dengan menyiram langsung di bedengan. Penyiangan gulma dilakukan secara periodik sesuai pertumbuhan gulma dan dilakukan secara manual. Pemasangan ajir tegak dilakukan saat tanam, sedangkan ajir samping saat tanaman mulai berbuah. Pewiwilan dilakukan untuk membuang tunas air untuk pembentukan batang tanaman tomat. Pemupukan dilakukan setiap satu minggu sekali setelah tanaman berumur 1 minggu setelah tanam (MST). Pengendalian hama dan penyakit tanaman dilakukan dengan penyemprotan pestisida yang dilakukan dua minggu sekali. Pemanenan dilakukan secara manual saat tanaman telah berumur 70-90 HST atau pada saat buah tomat telah mencapai tingkat kematangan $75 \%$. Pemanenan dilakukan secara bertahap selama tujuh kali panen.

Pengamatan dilakukan terhadap 10 tanaman contoh yang dipilih dari setiap satuan percobaan. Peubah yang diamati berdasarkan Pedoman Penyusunan Deskripsi Varietas Hortikultura oleh Direktorat Jenderal Hortikultura (2011) dan Descriptors for Tomato oleh IPGRI International Plant Genetic Resources Institute (1995). Karakter yang diamati meliputi tinggi tanaman, diameter batang, umur berbunga, umur panen, panjang buah, diameter buah, kekerasan buah yang diukur dengan alat penetrometer, tebal daging buah, bobot per buah, jumlah bunga per tanaman, jumlah buah per tanaman, jumlah tandan per tanaman, bobot buah per tanaman, produktivitas, dan kandungan padatan terlarut total yang diukur dengan alat hand refractrometer.

Penelitian ini menggunakan Rancangan Kelompok Lengkap Teracak (RKLT) satu faktor yaitu genotipe yang terdiri atas 13 genotipe potensial tomat dan dua varietas pembanding sebagai perlakuan. Percobaan dilakukan dalam tiga ulangan. Setiap satuan percobaan terdapat 15 genotipe sehingga terdapat 45 satuan percobaan. Setiap ulangan terdapat 20 tanaman dan diambil 10 tanaman contoh. Data yang diperoleh dianalisis dengan uji $\mathrm{F}$ menggunakan program SAS 9.0 untuk mengetahui pengaruh perlakuan, apabila hasil analisis yang diperoleh berpengaruh nyata maka dilakukan uji nilai tengah dengan uji tDunnett pada taraf 5\% untuk mengetahui perbedaan genotipe dengan varietas pembanding. Analisis korelasi dilakukan dengan program STAR IRRI untuk mengetahui keterkaitan antar peubah yang diamati.

\section{HASIL DAN PEMBAHASAN}

\section{Kondisi Umum}

Penelitian dilaksanakan di kebun percobaan Leuwikopo IPB yang memiliki ketinggian 207 mdpl. Penelitian dimulai bulan Februari hingga Juni 2015. Penyemaian benih dilakukan pada tray semai dengan daya berkecambah rata-rata tanaman tomat setiap genotipe berkisar 83-99\%. Kondisi iklim di sekitar lahan meliputi curah hujan berkisar antara 90-374 mm. Curah hujan tertinggi pada bulan Februari 2015 dan terendah pada bulan Juni 2015. Kelembaban udara berkisar antara 79-88\% dan suhu udara berkisar 25-26.2 ${ }^{\circ} \mathrm{C}$ (BMKG Dramaga, Bogor). Faktor lingkungan yang menyebabkan rendahnya produktivitas tomat di dataran rendah dipengaruhi oleh suhu lingkungan, curah hujan, dan kelembaban (Chupp dan Sherf, 1960). Lahan yang lembab dengan suhu yang tinggi menyebabkan banyaknya penyakit dan hama menyerang tanaman tomat selama masa penanaman.

Gejala penyakit cekik terlihat pada minggu pertama penanaman sehingga banyak tanaman yang disulam pada satu hari setelah pindah tanam hingga dua minggu. Penyakit cekik ditandai dengan batang bagian bawah menjadi busuk dan berwarna coklat kehitam-hitaman yang menyebabkan tanaman menjadi rebah, disebabkan oleh cendawan Pythium spp. Serangan penyakit ini diatasi dengan mencabut dan membuang tanaman yang sakit. Penyakit karat daun, virus kuning dan daun menggulung, serta penyakit busuk ujung buah (blossom end rot) adalah penyakit yang cukup dominan selama masa penanaman. Penyakit ini yang menyebabkan kekurangan hasil yang cukup besar pada tanaman tomat. Pengendalian penyakit dilakukan dengan membuang buah, daun dan mencabut tanaman yang sakit.

Penyakit lainnya yang menyerang adalah penyakit layu bakteri yang disebabkan oleh Ralstonia solanacearum, antraknosa, pecah buah, dan busuk buah. Hama yang dominan menyerang tanaman adalah belalang dan ulat buah (Helicoperva armigera). Pengendalian hama dan penyakit tersebut dilakukan secara kimiawi dengan pestisida.

\section{Karakter Kuantitatif}

Analisis ragam dilakukan untuk mengetahui pengaruh perlakuan terhadap karakter yang diamati. Hasil rekapitulasi sidik ragam menunjukkan perlakuan genotipe berpengaruh nyata pada taraf $1 \%$ terhadap karakter tinggi 
tanaman, umur berbunga, umur panen, jumlah tandan per tanaman, jumlah bunga per tanaman, jumlah buah per tanaman, bobot buah per tanaman, bobot per buah, panjang buah, diameter buah, tebal daging buah, fruit set, dan produktivitas. Perlakuan genotipe berpengaruh nyata pada taraf 5\% terhadap karakter diameter batang dan kekerasan buah (Tabel 1).

Hasil rekapitulasi sidik ragam juga menunjukkan berbagai nilai koefisien keragaman (KK) pada peubah yang diamati. Nilai KK menunjukkan tingkat ketepatan dengan perlakuan yang diperbandingkan dan merupakan indeks yang baik dari keadaan percobaan. (Gomez dan Gomez, 2007).

Nilai KK tertinggi ditunjukkan oleh peubah jumlah buah per tanaman, sementara nilai KK terendah dimiliki oleh peubah umur panen (Tabel 1). Nilai KK yang beragam menunjukkan bahwa lingkungan memberikan pengaruh yang bervariasi terhadap peubah yang diamati (Khasanah, 2013).

Tabel 1. Rekapitulasi sidik ragam karakter kuantitatif 15 genotipe tomat yang diamati

\begin{tabular}{|c|c|c|c|}
\hline Karakter & Genotipe & Nilai P & $\mathrm{KK}(\%)$ \\
\hline Tinggi tanaman $(\mathrm{cm})$ & $* *$ & 0.0017 & 4.01 \\
\hline Diameter batang (cm) & $*$ & 0.0232 & 5.45 \\
\hline Umur berbunga (HST) & $* *$ & 0.0028 & 3.21 \\
\hline Umur panen (HST) & $* *$ & 0.0000 & 1.83 \\
\hline Jumlah tandan per tanaman & $* *$ & 0.0045 & 9.01 \\
\hline Jumlah bunga per tanaman & $* *$ & 0.0000 & 9.42 \\
\hline Jumlah buah per tanaman & $* *$ & 0.0006 & 16.40 \\
\hline Bobot buah per tanaman $(\mathrm{g})$ & $* *$ & 0.0000 & 14.98 \\
\hline Bobot per buah (g) & $* *$ & 0.0003 & 5.71 \\
\hline Panjang buah $(\mathrm{cm})$ & $* *$ & 0.0000 & 4.06 \\
\hline Diameter buah $(\mathrm{cm})$ & $* *$ & 0.0089 & 4.82 \\
\hline Tebal Daging buah $(\mathrm{cm})$ & $* *$ & 0.0014 & 6.08 \\
\hline Padatan terlarut total ( ${ }^{\circ}$ Brix $)$ & $* *$ & 0.0000 & 5.78 \\
\hline Kekerasan buah (mm $\left.50 \mathrm{~g}^{-1} 5 \mathrm{~s}^{-1}\right)$ & $*$ & 0.0124 & 10.15 \\
\hline Fruit set $(\%)$ & $* *$ & 0.0063 & 9.16 \\
\hline Produktivitas (ton ha ${ }^{-1}$ ) & $* *$ & 0.0000 & 14.59 \\
\hline
\end{tabular}

Tinggi tanaman dan diameter batang genotipe tomat diamati pada saat tanaman telah berbuah dan menjelang panen, karena pada waktu tersebut tanaman telah mencapai pertumbuhan yang maksimal. Tinggi tanaman tomat yang diuji memiliki nilai rata-rata berkisar $81.43-94.53 \mathrm{~cm}$. Diameter batang memiliki nilai rata-rata berkisar $0.81-0.99 \mathrm{~cm}$.

Genotipe F8 005001-4-1-12-3-54-1, F8 005001-4-1-12-3-38-2, F8 005001-4-1-12-3-46-2, F8 005001-4-1-12-3-48-1, serta varietas pembanding Ratna memiliki nilai tengah yang tinggi dari semua genotipe yang diuji untuk karakter tinggi tanaman. Tinggi tanaman genotipe F8 005001-4-1-12-3-48-1 berbeda nyata lebih tinggi dari varietas pembanding Intan, sedangkan genotipe F8 005001-4-1-12-3-17-1, F8 005001-41-12-3-17-4, dan F8 005001-4-1-12-3-8-1 memiliki nilai tengah yang berbeda nyata lebih rendah dari varietas pembanding Ratna. Genotipe lainnya tidak berbeda nyata dibanding varietas pembanding Intan dan Ratna (Tabel 2).

Terdapat enam genotipe yang memiliki diameter batang lebih tinggi dari varietas pembanding Intan, yaitu F8 005001-4-1-12-3-483, F8 005001-4-1-12-3-17-4, F8 005001-4-1-123-87-3, F8 005001-4-1-12-3-54-1, F8 005001-4-
1-12-3-66-2, dan F8 005001-4-1-12-3-38-2, sementara genotipe lainnya memiliki diameter batang yang tidak berbeda nyata dengan varietas pembanding Intan dan Ratna (Tabel 2).

Umur berbunga dan umur panen ditentukan dari jumlah hari setelah pindah tanam hingga 50\% populasi tanaman muncul bunga dan $50 \%$ populasi tanaman berbuah sudah siap panen. Umur berbunga dan umur panen genotipe yang diuji memiliki nilai yang cukup bervariasi, umur berbunga genotipe yang diuji memiliki nilai berkisar antara 34-38 HST, sementara umur panennya berkisar antara 66-75 HST. Perbedaan umur berbunga dan umur panen genotipe tomat yang diuji disebabkan oleh faktor genetik yaitu umur tanaman.

Genotipe tomat yang diuji memiliki umur berbunga yang lebih lama (36-38 HST) dibandingkan kedua varietas pembanding Intan dan Ratna yang memiliki umur berbunga 34 HST. Genotipe F8 005001-4-1-12-3-48-3, F8 005001-41-12-3-17-4, dan F8 005001-4-1-12-3-46-2 memiliki umur berbunga berbeda nyata lebih lama dengan varietas pembanding Intan. Genotipe F8 005001-4-1-12-3-17-2, F8 005001-4-1-12-3-54-1, F8005001-4-1-12-3-66-2, F8 005001-4-1-12-388-1, F8 005001-4-1-12-3-38-2, dan F8 005001- 
4-1-12-3-48-1 memiliki umur berbunga yang berbeda nyata lebih lama dari varietas pembanding Intan dan Ratna (Tabel 2).

Varietas Intan memiliki umur panen paling cepat (66 HST) dibanding semua genotipe tomat yang diuji. Genotipe F8 005001-4-1-12-317-1, F8 005001-4-1-12-3-87-3, F8 005001-4-112-3-8-1, dan F8 005001-4-1-12-3-48-1 memiliki umur panen yang berbeda nyata lebih lama dibanding varietas pembanding Intan, sedangkan genotipe lainnya memiliki umur panen yang berbeda nyata lebih lama dari varietas pembanding Ratna (Tabel 2). Menurut Jones 2007, umur panen tanaman tomat dikatakan genjah antara 50-65 HST, sedang antara 65-80 HST, dan dalam antara 85-95 HST. Berdasarkan hal tersebut, genotipe tomat yang diuji dan varietas pembanding termasuk dalam kategori tomat berumur panen sedang.

Fruit set menunjukkan persentase jumlah terbentuknya buah dari sejumlah bunga dalam tandan yang dihasilkan oleh masing-masing genotipe tomat yang diuji (Khasanah, 2013). Persentase fruit set dihitung dengan membagi jumlah tandan buah per tanaman dengan jumlah tandan bunga per tanaman dikalikan 100\% (Santosa 2014). Persentase fruit set pada penelitian memiliki nilai berkisar antara 50-57\% (Tabel 2), nilai ini menunjukkan jumlah bunga dalam satu tandan yang dapat membentuk buah hanya setengahnya. Tabel 2 memperlihatkan bahwa genotipe F8 005001-4-1-12-3-87-3 dan F8 005001-4-1-12-3-8-1 memiliki nilai fruit set yang berbeda nyata lebih tinggi dari varietas pembanding Intan.

Tabel 2. Nilai tengah karakter tinggi, diameter, umur berbunga, umur panen, dan fruit set 13 genotipe tomat dan varietas pembanding

\begin{tabular}{llllll}
\hline \multicolumn{1}{c}{ Genotipe } & $\begin{array}{c}\text { Tinggi } \\
(\mathrm{cm})\end{array}$ & $\begin{array}{c}\text { Diameter } \\
(\mathrm{cm})\end{array}$ & $\begin{array}{c}\text { Umur berbunga } \\
(\mathrm{HST})\end{array}$ & $\begin{array}{c}\text { Umur panen } \\
(\text { HST })\end{array}$ & $\begin{array}{c}\text { Fruit set } \\
(\%)\end{array}$ \\
\hline F8 005001-4-1-12-3-17-1 & $81.43 \mathrm{~b}$ & 0.93 & 36 & $75 \mathrm{a}$ & 55 \\
F8 005001-4-1-12-3-17-2 & 86.30 & 0.90 & $38 \mathrm{ab}$ & $74 \mathrm{ab}$ & 56 \\
F8 005001-4-1-12-3-48-3 & 89.40 & $0.97 \mathrm{a}$ & $37 \mathrm{a}$ & $75 \mathrm{ab}$ & 56 \\
F8 005001-4-1-12-3-17-4 & $84.47 \mathrm{~b}$ & $0.97 \mathrm{a}$ & $37 \mathrm{a}$ & $75 \mathrm{ab}$ & 56 \\
F8 005001-4-1-12-3-87-3 & 89.57 & $0.99 \mathrm{a}$ & 36 & $73 \mathrm{a}$ & $55 \mathrm{a}$ \\
F8 005001-4-1-12-3-8-1 & $82.60 \mathrm{~b}$ & 0.94 & 36 & $73 \mathrm{a}$ & $55 \mathrm{a}$ \\
F8 005001-4-1-12-3-54-1 & 91.03 & $0.97 \mathrm{a}$ & $38 \mathrm{ab}$ & $74 \mathrm{ab}$ & 56 \\
F8 005001-4-1-12-3-66-1 & 89.53 & 0.94 & 36 & $74 \mathrm{ab}$ & 55 \\
F8 005001-4-1-12-3-46-2 & 91.80 & 0.92 & $37 \mathrm{a}$ & $75 \mathrm{ab}$ & 56 \\
F8 005001-4-1-12-3-66-2 & 88.42 & $0.96 \mathrm{a}$ & $37 \mathrm{ab}$ & $75 \mathrm{ab}$ & 56 \\
F8 005001-4-1-12-3-88-1 & 87.00 & 0.93 & $37 \mathrm{ab}$ & $75 \mathrm{ab}$ & 56 \\
F8 005001-4-1-12-3-38-2 & 91.20 & $0.98 \mathrm{a}$ & $38 \mathrm{ab}$ & $75 \mathrm{ab}$ & 57 \\
F8 005001-4-1-12-3-48-1 & $92.33 \mathrm{a}$ & 0.96 & $37 \mathrm{ab}$ & $73 \mathrm{a}$ & 55 \\
\hline Intan & 83.22 & 0.81 & 34 & 66 & 71 \\
Ratna & 94.53 & 0.95 & 34 & 50 \\
\hline
\end{tabular}

Keterangan: $\quad$ HST $=$ hari setelah tanam; $a=$ berbeda nyata dengan varietas pembanding Intan, $b=$ berbeda nyata dengan varietas pembanding Ratna, berdasarkan uji t-Dunnett taraf 5\%

Pengukuran panjang buah dan diameter buah dilakukan untuk mengetahui bentuk buah. Seluruh genotipe tomat yang diuji memiliki nilai tengah panjang buah yang berbeda nyata lebih panjang dibanding varietas Intan, tetapi tidak berbeda nyata dengan varietas pembanding Ratna. Genotipe F8 005001-4-1-12-3-48-3 memiliki panjang buah yang lebih panjang $(5.27 \mathrm{~cm})$ dari genotipe lainnya, sedangkan yang memiliki panjang buah paling kecil adalah varietas Intan (Tabel 3).

Diameter buah tomat yang diuji berkisar antara 3.68-4.45 cm. Seluruh genotipe yang diuji tidak berbeda nyata dari varietas pembanding Intan. Genotipe yang memiliki nilai diameter buah yang berbeda nyata lebih tinggi dibanding varietas Ratna adalah F8 005001-4-112-3-17-1, F8 005001-4-1-12-3-17-4, F8
005001-4-1-12-3-87-3, F8 005001-4-1-12-3-661, dan F8 005001-4-1-12-3-88-1, sementara genotipe lainnya tidak berbeda nyata dengan varietas pembanding Ratna (Tabel 3).

Ketebalan daging buah genotipe yang diuji memiliki nilai berkisar antara $0.37-0.52 \mathrm{~cm}$. Seluruh genotipe yang diuji kecuali varietas pembanding Intan termasuk dalam kriteria baik untuk karakter tebal daging buah. Hal ini sesuai dengan pernyataan Suryadi et al. (2004) bahwa kriteria tebal daging buah tomat yang baik adalah $0.4 \mathrm{~cm}$. Seluruh genotipe memiliki nilai tebal daging buah yang nyata lebih tebal dibanding varietas Intan (Tabel 3).

Pengukuran kandungan padatan terlarut total (PTT) menggunakan alat hand refractrometer. PTT adalah indeks yang menunjukkan proporsi refraktrometrik ( $\left.{ }^{\circ} \mathrm{Brix}\right)$ 
dari padatan terlarut dalam suatu larutan. PTT memiliki keterkaitan hubungan dalam penentuan rasa yang terkandung dalam tomat. Menurut Jones (2007), kandungan PTT tomat pada umumnya berkisar 5-7\%. Kandungan PTT pada penelitian berkisar antara 4.04-5.84 ${ }^{\circ}$ Brix. Genotipe F8 005001-4-1-12-3-17-2 memiliki kandungan PTT yang tertinggi $\left(5.84{ }^{\circ}\right.$ Brix $)$ di antara seluruh genotipe yang diuji dan berbeda nyata dibanding varietas Intan. Genotipe tomat yang lainnya juga menunjukkan nilai kandungan PTT yang berbeda nyata lebih tinggi dibanding varietas Intan (Tabel 3).

Kekerasan buah ditentukan dengan menggunakan alat penetrometer. Nilai kekerasan buah menunjukkan tingkat kedalaman jarum yang ditusukkan ke buah, semakin dalam tusukan atau semakin besar nilai kekerasan buah menunjukkan buah tersebut semakin lunak (Baharuddin et al., 2014). Kekerasan buah yang diamati memiliki nilai berkisar 30.09-44.19 mm $50 \mathrm{~g}^{-1} 5 \mathrm{~s}^{-1}$. Genotipe F8 005001-4-1-12-3-87-3 dan F8 005001-4-1-12-3-38-2 memiliki nilai tengah kekerasan buah yang tidak berbeda nyata dengan kedua varietas pembanding, sementara genotipe lainnya memiliki nilai kekerasan buah yang nyata lebih rendah dibanding varietas Intan. Genotipe F8 005001-4-1-12-3-17-2 memiliki nilai kekerasan buah yang tinggi, sementara varietas Intan memiliki nilai kekerasan buah yang rendah (Tabel 3). Wijayani dan Widodo (2005) menyatakan, kekerasan buah akan mempengaruhi ketahanan buah tomat terhadap kerusakan mekanis dan erat kaitannya dengan kandungan kadar air pada buah tersebut, semakin tinggi kadar air maka buah akan semakin lunak. Menurut Husniyah et al. (2007) konsumen lebih menyukai tomat berkulit keras atau tegar karena dapat disimpan lebih lama.

Tabel 3. Nilai tengah karakter panjang buah, diameter buah, tebal daging buah, padatan terlarut total, dan kekerasan buah 13 genotipe tomat dan varietas pembanding

\begin{tabular}{lccccc}
\hline Genotipe & $\begin{array}{c}\text { Panjang buah } \\
(\mathrm{cm})\end{array}$ & $\begin{array}{c}\text { Diameter buah } \\
(\mathrm{cm})\end{array}$ & $\begin{array}{c}\text { Tebal daging } \\
\text { buah }(\mathrm{cm})\end{array}$ & $\begin{array}{c}\text { Padatan terlarut } \\
\text { total }\end{array}$ & $\begin{array}{c}\text { Kekerasan buah } \\
\left(\mathrm{mm}^{5} \mathrm{~g}^{-1} 5 \mathrm{~s}^{-1}\right)\end{array}$ \\
\hline F8 005001-4-1-12-3-17-1 & $4.89 \mathrm{a}$ & $4.18 \mathrm{~b}$ & $0.50 \mathrm{a}$ & $5.45 \mathrm{a}$ & $32.94 \mathrm{a}$ \\
F8 005001-4-1-12-3-17-2 & $4.84 \mathrm{a}$ & 4.16 & $0.48 \mathrm{a}$ & $5.84 \mathrm{a}$ & $30.09 \mathrm{a}$ \\
F8 005001-4-1-12-3-48-3 & $5.27 \mathrm{a}$ & 4.02 & $0.49 \mathrm{a}$ & $5.22 \mathrm{a}$ & $32.09 \mathrm{a}$ \\
F8 005001-4-1-12-3-17-4 & $4.89 \mathrm{a}$ & $4.25 \mathrm{~b}$ & $0.49 \mathrm{a}$ & $5.00 \mathrm{a}$ & $33.64 \mathrm{a}$ \\
F8 005001-4-1-12-3-87-3 & $5.19 \mathrm{a}$ & $4.44 \mathrm{~b}$ & $0.51 \mathrm{a}$ & $4.91 \mathrm{a}$ & 36.00 \\
F8 005001-4-1-12-3-8-1 & $5.05 \mathrm{a}$ & 4.05 & $0.50 \mathrm{a}$ & $5.45 \mathrm{a}$ & $32.54 \mathrm{a}$ \\
F8 005001-4-1-12-3-54-1 & $4.58 \mathrm{a}$ & 4.14 & $0.50 \mathrm{a}$ & $5.35 \mathrm{a}$ & $31.36 \mathrm{a}$ \\
F8 005001-4-1-12-3-66-1 & $4.87 \mathrm{a}$ & $4.32 \mathrm{~b}$ & $0.49 \mathrm{a}$ & $4.97 \mathrm{a}$ & $33.66 \mathrm{a}$ \\
F8 005001-4-1-12-3-46-2 & $5.15 \mathrm{a}$ & 4.17 & $0.50 \mathrm{a}$ & $5.29 \mathrm{a}$ & $32.28 \mathrm{a}$ \\
F8 005001-4-1-12-3-66-2 & $5.02 \mathrm{a}$ & 4.08 & $0.48 \mathrm{a}$ & $5.38 \mathrm{a}$ & $35.18 \mathrm{a}$ \\
F8 005001-4-1-12-3-88-1 & $5.05 \mathrm{a}$ & $4.45 \mathrm{~b}$ & $0.49 \mathrm{a}$ & $4.80 \mathrm{a}$ & $33.78 \mathrm{a}$ \\
F8 005001-4-1-12-3-38-2 & $5.22 \mathrm{a}$ & 4.12 & $0.50 \mathrm{a}$ & $5.32 \mathrm{a}$ & 36.17 \\
F8 005001-4-1-12-3-48-1 & $5.26 \mathrm{a}$ & 3.94 & $0.51 \mathrm{a}$ & $5.46 \mathrm{a}$ & $32.31 \mathrm{a}$ \\
\hline Intan & 4.13 & 4.32 & 0.37 & 4.04 & 44.19 \\
Ratna & 5.01 & 3.68 & 0.52 & 5.51 & 33.50 \\
\hline Ket & & &
\end{tabular}

Keterangan: a=berbeda nyata dengan varietas pembanding Intan, b=berbeda nyata dengan varietas pembanding Ratna, berdasarkan uji t-Dunnett taraf 5\%

Pengamatan jumlah tandan per tanaman, jumlah tandan bunga per tanaman, dan jumlah buah per tanaman dilakukan dari setiap genotipe tomat pada saat panen pertama hingga terakhir. Jumlah tandan per tanaman genotipe F8 0050014-1-12-3-17-2, F8 005001-4-1-12-3-48-3, F8 005001-4-1-12-3-54-1, dan F8 005001-4-1-12-366-1 memiliki nilai berbeda nyata lebih banyak dibandingkan varietas Intan, sementara hanya genotipe F8 005001-4-1-12-3-17-1 yang memiliki jumlah tandan per tanaman lebih sedikit dari varietas pembanding Ratna. Genotipe lainnya memiliki jumlah tandan per tanaman yang tidak berbeda nyata dengan varietas Intan dan Ratna (Tabel 4).
Jumlah buah per tanaman genotipe F8 005001-4-1-12-3-87-3, F8 005001-4-1-12-3-66-1, dan F8 005001-4-1-12-3-66-2 memiliki nilai yang berbeda nyata lebih tinggi dibanding varietas Intan dan tidak berbeda nyata dibanding varietas Ratna (Tabel 4). Genotipe yang berbeda nyata dengan varietas pembanding Ratna adalah F8 005001-4-1-12-3-17-1 dan F8 005001-4-1-12-317-2, namun memiliki jumlah buah per tanaman yang lebih rendah. Berdasarkan Tabel 4 hanya genotipe F8 005001-4-1-12-3-54-1 yang memiliki jumlah bunga per tanaman yang berbeda nyata lebih tinggi dari varietas pembanding Intan dan tidak berbeda nyata dengan varietas pembanding Ratna. Dua belas genotipe lainnya memiliki 
jumlah bunga per tanaman yang berbeda nyata dengan varietas pembanding Intan dan Ratna.

Bobot per buah pada penelitian berkisar antara 36.31-47.69 g. Genotipe F8 005001-4-112-3-17-1, F8 005001-4-1-12-3-17-2, dan F8 005001-4-1-12-3-88-1 berbeda nyata dengan varietas Intan namun lebih rendah, sedangkan genotipe F8 005001-4-1-12-3-87-3 memiliki bobot per buah yang berbeda nyata lebih tinggi dibanding varietas Ratna (Tabel 4).

Bobot buah per tanaman ditentukan dengan menjumlahkan hasil panen pertama hingga panen terakhir. Bobot buah per tanaman genotipe yang diuji berkisar antara 487.32-924.94 g. Genotipe F8 005001-4-1-12-3-87-3 dan F8 005001-4-1-12-3-66-1 berbeda nyata lebih tinggi dengan varietas pembanding Intan dan tidak berbeda nyata dengan varietas pembanding Ratna (Tabel 4). Hal ini berarti kedua genotipe tersebut memiliki bobot buah per tanaman yang sama baiknya dengan varietas Ratna, sementara tiga genotipe yang memiliki bobot buah per tanaman yang berbeda nyata lebih rendah dibanding varietas Ratna yaitu genotipe F8 005001-4-1-123-17-1, F8 005001-4-1-12-3-17-2, dan F8 005001-4-1-12-3-8-1.

Produktivitas genotipe tomat memiliki nilai berkisar 15.59-29.60 ton ha ${ }^{-1}$. Genotipe yang memiliki produktivitas nyata lebih tinggi dari varietas pembanding Intan adalah F8 005001-4-112-3-87-3, F8 005001-4-1-12-3-66-1, dan F8 005001-4-1-12-3-66-2, sedangkan genotipe F8 005001-4-1-12-3-17-1, F8 005001-4-1-12-3-17-2, F8 005001-4-1-12-3-48-3, dan F8 005001-4-1-123-8-1 memiliki nilai produktivitas yang nyata lebih rendah dari varietas pembanding Ratna (Tabel 4).

Tabel 4. Nilai tengah karakter komponen hasil 13 genotipe tomat dan varietas pembanding

\begin{tabular}{|c|c|c|c|c|c|c|}
\hline Genotipe & $\begin{array}{l}\text { Bobot per } \\
\text { buah }\end{array}$ & $\begin{array}{l}\text { Jumlah tandan } \\
\text { per tanaman }\end{array}$ & $\begin{array}{l}\text { Jumlah buah } \\
\text { per tanaman }\end{array}$ & $\begin{array}{l}\text { Jumlah bunga } \\
\text { per tanaman }\end{array}$ & $\begin{array}{l}\text { Bobot buah } \\
\text { per tanaman }\end{array}$ & Produktivitas \\
\hline F8 $005001-4-1-12-3-17-1$ & $40.97 \mathrm{a}$ & $11 \mathrm{~b}$ & $16 b$ & $28 \mathrm{ab}$ & $487.32 b$ & $15.59 b$ \\
\hline F8 005001-4-1-12-3-17-2 & $36.31 \mathrm{a}$ & $15 \mathrm{a}$ & $17 b$ & $31 \mathrm{ab}$ & $543.40 b$ & $17.39 b$ \\
\hline F8 005001-4-1-12-3-48-3 & 42.06 & $14 \mathrm{a}$ & 20 & $28 \mathrm{ab}$ & 562.36 & $18.00 \mathrm{~b}$ \\
\hline F8 005001-4-1-12-3-17-4 & 43.62 & 13 & 23 & $34 \mathrm{ab}$ & 639.62 & 20.71 \\
\hline F8 005001-4-1-12-3-87-3 & $46.77 b$ & 13 & $29 \mathrm{a}$ & $31 \mathrm{ab}$ & $924.94 a$ & $29.60 \mathrm{a}$ \\
\hline F8 005001-4-1-12-3-8-1 & 43.17 & 14 & 19 & $30 \mathrm{ab}$ & $535.34 b$ & $17.13 b$ \\
\hline F8 005001-4-1-12-3-54-1 & 44.70 & $14 \mathrm{a}$ & 22 & $36 \mathrm{a}$ & 600.78 & 19.23 \\
\hline F8 005001-4-1-12-3-66-1 & 43.88 & $15 \mathrm{a}$ & $29 a$ & $31 \mathrm{ab}$ & $873.99 a$ & $27.97 \mathrm{a}$ \\
\hline F8 005001-4-1-12-3-46-2 & 45.70 & 13 & 25 & $29 \mathrm{ab}$ & 699.77 & 22.39 \\
\hline F8 005001-4-1-12-3-66-2 & 44.29 & 12 & $29 \mathrm{a}$ & $39 \mathrm{ab}$ & 814.50 & $26.06 \mathrm{a}$ \\
\hline F8 005001-4-1-12-3-88-1 & $38.43 a$ & 13 & 22 & $31 \mathrm{ab}$ & 645.34 & 20.65 \\
\hline F8 005001-4-1-12-3-38-2 & 44.13 & 12 & 20 & $30 \mathrm{ab}$ & 567.17 & 18.15 \\
\hline F8 $005001-4-1-12-3-48-1$ & 41.69 & 13 & 26 & $30 \mathrm{ab}$ & 775.73 & 24.82 \\
\hline Intan & 47.69 & 11 & 19 & 19 & 582.02 & 18.62 \\
\hline Ratna & 40.48 & 14 & 28 & 41 & 806.64 & 25.81 \\
\hline
\end{tabular}

Keterangan: a) berbeda nyata dengan varietas pembanding Intan, b) berbeda nyata dengan varietas pembanding Ratna, berdasarkan uji t-Dunnett taraf 5\%

\section{Analisis Korelasi}

Korelasi antar sifat tanaman biasanya diukur dengan koefisien korelasi. Korelasi antar sifat tanaman penting dalam pemuliaan tanaman karena koefisien korelasi merupakan nilai dari hubungan antara dua sifat atau lebih (Asmara, 2011). Nilai korelasi yang positif terjadi sebagai akibat dari gen-gen pengendali antara karakterkarakter yang berkorelasi meningkat, sedangkan korelasi negatif menunjukkan bahwa penambahan suatu sifat akan diikuti dengan berkurangnya nilai sifat yang lain.

Karakter tinggi tanaman, panjang daun, dan jumlah buah per tanaman berkorelasi positif terhadap karakter bobot buah per tanaman (Tabel 5), artinya pertambahan tinggi tanaman, panjang daun, dan jumlah buah per tanaman akan diikuti dengan pertambahan bobot buah per tanaman yang dihasilkan.

Karakter panjang daun dan lebar daun berkorelasi positif terhadap karakter jumlah buah per tanaman (Tabel 5), yang berarti daun dengan ukuran yang lebih besar akan diikuti dengan pertambahan jumlah buah per tanaman, karena kapasitas daun dalam melakukan fotosintesis yang juga semakin besar.

Karakter umur berbunga nyata mempengaruhi terhadap karakter umur panen (Tabel 5), yang menunjukkan bahwa semakin lama tanaman berbunga maka akan semakin lama buah dapat dipanen. Karakter umur panen berkorelasi positif terhadap panjang buah dan tebal daging buah yang berarti untuk mendapatkan buah yang panjang dan daging buah yang tebal membutuhkan waktu panen yang lebih 
lama. Umur panen juga berkorelasi positif terhadap padatan terlarut total (PTT), namun berkorelasi negatif terhadap kekerasan buah (Tabel 5). Hal ini menunjukkan bahwa semakin lama buah tomat dapat dipanen maka semakin tinggi nilai total padatan terlarut

Karakter panjang buah memiliki korelasi positif terhadap karakter tebal daging buah, yang menunjukkan bahwa buah yang panjang cenderung memiliki daging buah yang lebih tebal. Karakter tebal daging buah memiliki korelasi yang negatif terhadap kekerasan buah. Hal tersebut menunjukkan bahwa tidak ada jaminan buah yang keras memiliki daging buah tebal (Tabel 5). Prihadi (1993) menyatakan bahwa kekerasan buah dipengaruhi oleh kondisi kulit epidermis yang tidak sama tingkat kelihatannya pada masing-masing genotipe, sehingga tidak terdapat hubungan yang jelas antara tebal daging buah dan kekerasan buah. Yunianti et al. (2010) mengatakan bahwa korelasi yang tinggi menunjukkan keeratan hubungan antar karakter dan tidak menunjukkan hubungan sebab akibat.

Tabel 5. Korelasi linier antar karakter kuantitatif 13 genotipe tomat dan varietas pembanding

\begin{tabular}{|c|c|c|c|c|c|c|c|c|c|c|c|}
\hline Karakter & $\mathrm{TT}$ & DT & UB & UP & $\mathrm{JT}$ & $\mathrm{JB}$ & PTT & $\mathrm{PB}$ & TDB & BPT & $\mathrm{BB}$ \\
\hline DT & $0.4^{\mathrm{tn}}$ & & & & & & & & & & \\
\hline UB & $0.1^{\text {tn }}$ & $0.4^{\text {tn }}$ & & & & & & & & & \\
\hline UP & $0.1^{\mathrm{tn}}$ & $0.7^{* *}$ & $0.7^{* *}$ & & & & & & & & \\
\hline JT & $0.3^{\text {tn }}$ & $0.2^{\text {tn }}$ & $0.2^{\text {tn }}$ & $0.2^{\text {tn }}$ & & & & & & & \\
\hline JB & $0.6^{*}$ & $0.4^{\text {tn }}$ & $-0.1^{\mathrm{tn}}$ & $0.0^{\mathrm{tn}}$ & $0.2^{\text {tn }}$ & & & & & & \\
\hline PTT & $0.2^{\mathrm{tn}}$ & $0.4^{\mathrm{tn}}$ & $0.4^{\text {tn }}$ & $0.5^{*}$ & $0.4^{\mathrm{tn}}$ & $-0.0^{\mathrm{tn}}$ & & & & & \\
\hline PB & $0.4^{\mathrm{tn}}$ & $0.7^{* *}$ & $0.3^{\mathrm{n}}$ & $0.6^{*}$ & $0.2^{\mathrm{tn}}$ & $0.2^{\text {tn }}$ & $0.5^{*}$ & & & & \\
\hline DB & $0.4^{\mathrm{tn}}$ & $-0.2^{\text {tn }}$ & $0.1^{\mathrm{tn}}$ & $0.0^{\mathrm{tn}}$ & $-0.1^{\mathrm{tn}}$ & $-0.0^{\mathrm{tn}}$ & $-0.6^{*}$ & $-0.2^{\mathrm{tn}}$ & & & \\
\hline TDB & $0.4^{\mathrm{tn}}$ & $0.8^{* *}$ & $0.3^{\text {tn }}$ & $0.7^{* *}$ & $0.4^{\mathrm{tn}}$ & $0.3^{\text {tn }}$ & $0.7^{* *}$ & $0.7^{* *}$ & & & \\
\hline $\mathrm{BPT}$ & $0.5^{*}$ & $0.3^{\text {tn }}$ & $-0.2^{\text {tn }}$ & $-0.0^{\operatorname{tn}}$ & $0.2^{\text {tn }}$ & $0.9^{* *}$ & $-0.1^{\mathrm{tn}}$ & $0.2^{\text {tn }}$ & $0.2^{\mathrm{tn}}$ & & \\
\hline $\mathrm{BB}$ & $0.0^{\text {tn }}$ & $-0.0^{\mathrm{tn}}$ & $-0.2^{\text {tn }}$ & $-0.3^{\mathrm{tn}}$ & $-0.3^{\text {tn }}$ & $0.3^{\text {tn }}$ & $-0.5^{*}$ & $-0.2^{\text {tn }}$ & $-0.3^{\mathrm{tn}}$ & $0.2^{\text {tn }}$ & \\
\hline $\mathrm{KB}$ & $-0.2^{\text {tn }}$ & $-0.5^{*}$ & $-0.5^{*}$ & $-0.7^{* *}$ & $-0.6^{*}$ & $0.0^{\mathrm{tn}}$ & $-0.8^{* *}$ & $-0.5^{*}$ & $-0.7^{* *}$ & $0.0^{\operatorname{tn}}$ & $0.6^{*}$ \\
\hline
\end{tabular}

\section{KESIMPULAN}

Genotipe tomat yang diuji memberikan pengaruh yang nyata terhadap karakter daya hasil tanaman, seperti tinggi tanaman, diameter batang, umur berbunga, umur panen, diameter buah, panjang buah, tebal daging buah, bobot per buah, jumlah buah per tanaman, dan bobot buah per tanaman. Genotipe yang diuji memiliki daya hasil yang lebih baik dibandingkan dengan varietas Intan. Genotipe F8 005001-4-1-12-3-87-3 memiliki bobot per buah dan produktivitas yang paling tinggi dibandingkan dengan semua genotipe yang diuji. Genotipe F8 005001-4-1-123-87-3 dan F8 005001-4-1-12-3-66-1 memiliki jumlah buah per tanaman dan bobot buah per tanaman lebih baik dari genotipe lainnya dan varietas pembanding. Seluruh genotipe memiliki panjang buah, tebal daging buah, dan padatan terlarut total (PTT) yang lebih tinggi dari varietas pembanding Intan.

\section{DAFTAR PUSTAKA}

Ambarwati, E., Murti, R.H., Trisnowati, S. 2009. Perakitan tomat berproduksi tinggi untuk dataran tinggi dan dataran rendah. Laporan Akhir Hasil Penelitian Hibah Bersaing XVI Universitas Gadjah Mada. Yogyakarta (ID): Universitas Indonesia.

Apriyanti, L.H. 2013. Daya hasil galur harapan tomat (Solanum lycopersicon L.) di dataran rendah [skripsi]. Bogor (ID): Institut Pertanian Bogor.

Asmara, P.E.S. 2011. Uji daya hasil galur harapan tomat (Lycopersicon esculentum Mill.) [skripsi]. Yogyakarta (ID): Universitas Gadjah Mada.

Baharuddin, R., Chozin, M.A., Syukur, M. 2014. Toleransi 20 genotipe tanaman tomat terhadap naungan. J Agron Indonesia 42(2): 130-135. 
Chupp, C., Sherf, A.F. 1960. Vegetable Diseases and Their Control. New York (US): Ronald Pr.

[Ditjenhorti] Direktorat Jenderal Hortikultura. 2011. Pedoman Penyusunan Deskripsi Varietas Hortikultura. Jakarta (ID): Kementerian Pertanian.

Gomez, K.A., Gomez, A.A. 2007. Prosedur Statistik untuk Penelitian Pertanian. Sjamsuddin E, Baharsjah JS, penerjemah. Jakarta (ID): UI Press. Terjemah dari: Statistical Procedures for Agriculture Research.

Husniyah, A., Murti, R.H., Trisnowati, S. 2007. Evaluasi kualitas buah sebelas kultivar tomat (Lycopersicum esculentum Mill.) hasil budi daya organik dan konvensional. Simposium, Seminar, dan Kongres IX Perhimpunan Agronomi Indonesia (PERAGI) [Internet]. [2007 Nov 15-17]. Bandung (ID): hlm 224231; [diunduh 2014 Feb 21]. Tersedia pada: http://lib.ugm.ac.id

Jones, B.J. 2007. Tomato Plant Culture: in the field, greenhouse, and home garden. New York (US): CRC Press.

Khasanah, U. 2013. Evaluasi karakter dan daya hasil beberapa genotipe tomat (Lycopersicon esculentum Mill.) di kebun percobaan IPB Tajur, Bogor [skripsi]. Bogor (ID): Institut Pertanian Bogor.

Kuswanto, Kasno, A., Soetopo, L., Hadiastono, T. 2005. Uji daya hasil pendahuluan dan seleksi ketahanan galur-galur harapan kacang panjang Unibraw terhadap cabmv. Publikasi Penelitian Hibah Bersaing XI/3-2. Malang (ID): Universitas Brawijaya.
Kuswanto, Waluyo, B., Soetopo, L., Afandhi, A. 2009. Uji daya hasil galur harapan kacang panjang toleran hama aphid dan berdaya hasil tinggi. Agrivita. 31(1):3140.

Purwati, E. 2007. Varietas unggul harapan tomat hibrida (F1) dari balitsa. Iptek Hortikultura. 3:34-40. Purwati E. 2009. Daya hasil tomat hibrida (F1) di dataran medium. J Hort. 19(2):125-130.

[Pusdatin] Pusat Data dan Sistem Informasi Pertanian. 2014. Volume impor komoditas hortikultura Indonesia [Internet]. [diunduh 2015 Agt 24]. http://pusdatin.setjen.pertanian.go.id/.

Prihadi, T. 1993. Uji daya hasil dan penilaian kualitas tomat di dataran rendah [skripsi]. Bogor (ID): Institut Pertanian Bogor.

Santosa, A. 2014. Evaluasi daya hasil 12 genotipe tomat (Solanum lycopersicum L.) dengan 3 pembanding [skripsi]. Bogor (ID): Institut Pertanian Bogor.

Surmaini, E.E., Runtunuwu, I.L. 2008. Upaya sektor pertanian dalam menghadapi perubahan iklim. J Litbang Pertanian. (30):1-7.

Wijayani, A, Widodo, W. 2005. Usaha meningkatkan kualitas beberapa varietas tomat dengan system budi daya hidroponik. J Ilmu Pertanian 12(1):7783.

Yunianti, R., Sartrosmarjo, S., Sujiprihati, S., Surahman M., Hidayat S.H. 2010. Kriteria seleksi untuk perakitan varietas cabai tahan Phytophthora capsici Leonian. J agron Indonesia 38(2):122129. 